Oktober 2017 Volume 01 No. 01

\title{
ANALYSIS OF THE BUSINESS ECONOMICS OF DUCKLINGS IN LANGKAT REGENCY
}

\section{ANALISA EKONOMI USAHA TERNAK ITIK PEDAGING DI KABUPATEN LANGKAT}

\author{
Muhammad Buchari Sibuea \\ Program Studi Agribisnis Fakultas Pertanian \\ Universitas Muhammadiyah Sumatera Utara \\ email : $\underline{\text { buchari65@yahoo.com }}$
}

\begin{abstract}
The research was conducted in Pematang Cengal Barat Village, Tanjung Pura Sub-district, Langkat Regency, to identify and know the availability of production input, business management system, the amount of business income and the contribution of the broiler duck business income to the overall income which also works as rice farmer. The research area is determined purposively considering the typical characteristics of this business. The population of 30 people used as a sample of research. The data obtained were analyzed descriptively.

From the result of the research, it is found that proportional availability of input or production factor for this business is quite good. While the business management system of broiler duck is still done simply and traditionally but showed better results. Revenue earned by broiler ducks is quite high per season and even the contribution of this broiler duck to total income than farmers is bigger than their main business from rice farming.

The results recommend that farmers make livestock business as the main business which maintenance can be done extensively and intensively so as to produce good productivity.

Keywords: economic analysis, broiler duck

\section{ABSTRAK}

Penelitian dilaksanakan di Desa Pematang Cengal Barat Kecamatan Tanjung Pura Kabupaten Langkat dengan tujuan untuk mengidentifikasi dan mengetahui ketersediaan input produksi, sistim pengelolaan usaha, besarnya pendapatan usaha dan kontribusi pendapatan usaha ternak itik pedaging terhadap pendapatan secara keseluruhan yang sekaligus juga berprofesi sebagai petani padi sawah. Daerah penelitian ditentukan secara purposive mengingat karakteristik yang khas dari usaha ini. Populasi berjumlah 30 orang dijadikan sebagai sampel penelitian. Data-data yang diperoleh dianalisa secara deskriptif.

Dari hasil penelitian diperoleh bahwa secara proporsional ketersedian input atau faktor produksi untuk usaha ini tersedia cukup baik. Sedangkan sistim pengelolaan usaha ternak itik pedaging masih dilakukan secara sederhana dan tradisional tetapi memperlihatkan hasil yang baik. Pendapatan yang diterima oleh peternak itik pedaging cukup tinggi per musimnya dan bahkan kontribusi usaha ternak itik pedaging ini terhadap pendapatan total daripada petani justeru lebih besar dibandingkan usaha pokok mereka dari usaha tani padi sawah.

Hasil penelitian merekomendasikan agar petani menjadikan usaha peternakan sebagai usaha pokok yang pemeliharaannya dapat dilakukan secara ekstensif dan intensif sehingga dapat menghasilkan produktivitas baik.
\end{abstract}

Kata kunci : analisa ekonomi, ternak itik pedaging

\section{A. PENDAhuluan}

Produktifitas padi sawah yang tinggi dan harga jual gabah yang baik, membawa keuntungan usaha bagi petani padi sawah, yaitu petani pemilik lahan yang luas, lebih dari satu hektar. Untuk dapat meningkatkan kesejahteraan petani padi sawah, petani harus memiliki lahan sawah sendiri, idealnya minimal dua hektar per kepala keluarga. Seperti halnya di Thailand rata-rata petaninya memiliki luas lahan garapan lima hektar per kepala keluarga, di Malaysia empat hektar per kepala keluarga dan bahkan di Australia mencapai 100 hektar per kepala keluarga ${ }^{1}$. Sayangnya petani padi sawah di Indonesia kepemilikan lahan sawahnya rata-rata hanya 0,7 hektar per kepala keluarga. Di
Jawa Barat memang ada beberapa petani yang luas lahannya sawahnya mencapai 50 hektar, bahkan ada yang lebih. Akan tetapi, jumlah pemilik lahan yang luasnya demikian hanya sedikit, kurang dari $1 \%$. 2

Salah satu jalan keluar yang dapat ditempuh untuk dapat meningkatkan pendapatan petani padi sawah yaitu dengan merekayasa lahan sawah dengan teknologi tepat guna, dengan cara mengubah strategi pertanian dari sistim monokultur ke arah diversifikasi pertanian, misalnya dengan perikanan dan peternakan. Perubahan strategi ini diharapkan dapat memenuhi kebutuhan pangan dan meningkatkan pendapatan petani padi sawah. Dalam hal ini, sistim 
diversifikasi pertanian yang digunakan ialah ternak itik pedaging. Sistim beternak itik pedaging di lahan padi sawah merupakan salah satu sistim yang praktis untuk meningkatkan pemanfaatan lahan padi sawah dan pemanfaatan sumberdaya lahan padi sawah yang cukup melimpah ${ }^{3}$. Itik pedaging habitat hidupnya membutuhkan kolam air dalam hal ini lahan padi sawah menyediakan habitat yang baik dan pakan alami yang melimpah. Diduga usaha ternak itik pedaging sebagai usaha sampingan pendapatannya lebih besar dibandingkan dengan usaha padi sawah sebagai usaha utama. ${ }^{4}$

Itik pedaging merupakan ternak unggas penghasil daging yang sangat potensial di samping ayam. Kelebihan ternak itik pedaging adalah tahan terhadap penyakit dibandingkan dengan ternak yang lain sehingga pemeliharaannya mudah dan tidak banyak mengandung resiko. Itik mampu berproduksi dengan baik, oleh karena itu pengembangannya diarahkan kepada produksi yang cepat dan tinggi sehingga mampu memenuhi permintaan konsumen. ${ }^{2}$

China merupakan produsen daging itik terbesar dengan tingkat produksi 2.643.800 ton. Indonesia hanya memproduksi 25.800 ton, Malaysia memproduksi 107.900 ton. Di bawah Indonesia adalah Bangladesh dengan produksi sebanyak 23.000 ton. Sedangkan negara Asia lain seperti India, Korea Selatan, Myanmar, Thailand dan Vietnam, secara berturut-turut memproduksi 46.200 ton; 55.000 ton; 81.000 ton; 77.400 ton dan 80.600 ton. $^{5}$

Pengembangan ternak itik di Langkat semakin meningkat dan saat ini populasinya sudah mencapai 205.119 ekor. Berbagai upaya dan terobosan telah dilakukan untuk memberdayakan masyarakat maupun petani untuk mengembangkan ternak itik misalnya dengan memberikan bantuan sehingga sekarang ini ternak itik merupakan salah satu alternatif menambah pendapatan. Jumlah itik sekarang ini telah mencapai 205.119 ekor, sedangkan jumlah telur yang dihasilkan pada tahun 2012 mencapai 33,4 ton. ${ }^{6}$

Dengan meningkatnya populasi itik terkadang peternak itik pedaging terkena dampak rendahnya harga jual. Hal ini dikarenakan banyaknya petani yang ikut beternak itik sedangkan pedagang pembeli tetap jumlahnya sehingga pedagang menurunkan harga. Kemudian dengan banyaknya itik yang digembala mengakibatkan persaingan mendapatkan pakan alami semakin ketat yang mengakibatkan itik kekurangan makanan. ${ }^{7}$

Usaha peternakan itik memiliki prospek usaha yang potensial untuk dikembangkan maupun untuk dipasarkan, baik usaha pokok maupun sebagai usaha sampingan, sehingga sangat membantu dalam meningkatkan pendapatan. ${ }^{8}$ Model peternakan itik kebanyakan tradisional yang skala pemeliharannya kecil dan model pemberian pakan mengandalkan pakan alami. Saat ini berkembang usaha ternak itik untuk pemenuhan kebutuhan daging dan untuk kebutuhan telur yang sudah ada sebelumnya. Seiring dengan semakin tumbuhnya warung makan serba bebek, kebutuhan itik pedaging tidak kalah dengan bebek petelur. Selain itu pemenuhan daging itik dari itik afkir saat ini sudah tidak mencukupi. ${ }^{3}$

Berdasarkan survei, peternak itik pedaging memanfaatkan lahan panen padi sawah sebagai tempat beternak dengan harapan dapat memenuhi kebutuhan protein hewani dan mendapatkan keuntungan produk yang maksimal. Pemanfaatan lahan panen padi sawah sebagai tempat beternak memberi dampak positif yang dapat diperoleh petani yakni peningkatan pendapatan. Dalam hal ini para petani juga akan memperoleh keuntungan lainnya, yaitu tersedianya pakan alami bagi itik pedaging, hama penyakit di lahan menjadi berkurang, kesuburan tanah meningkat. ${ }^{9}$

Di Desa Pematang Cengal Barat Kecamatan Tanjung Pura Kabupaten Langkat, penduduknya merupakan bermata pencaharian sebagai petani, peternak, nelayan. Komoditi yang paling banyak diusahakan di daerah ini adalah padi sawah. Untuk dapat memenuhi kebutuhan hidupnya masyarakat juga mengusahakan beberapa kegiatan usaha sampingan seperti nelayan, ternak sapi dan kambing serta ternak itik pedaging yang cukup menjanjikan dan diduga menjadi usaha sampingan yang hasilnya lebih besar dari usahatani padi sawah sebagai usaha pokok.

\section{B. METODE PENELITIAN}

Metode penelitian digunakan adalah case study yaitu penelitian yang dilakukan dengan melihat langsung ke lapangan, karena studi kasus merupakan metode yang menjelaskan jenis penelitian mengenai suatu objek tertentu selama kurun waktu atau suatu fenomena yang ditemukan pada suatu tempat yang belum tentu sama dengan daerah lain.

\section{Metode Penentuan Lokasi}

Penentuan daerah penelitian dilakukan secara purposive yaitu di Desa Pematang Cengal Barat Kecamatan Tanjung Pura Kabupaten Langkat. Alasan pemilihan daerah ini adalah karena desa ini merupakan salah satu desa yang mempunyai usaha beternak itik yang khas dan unik.

\section{Metode Penarikan Sampel}

Populasi dari penelitian adalah petani padi sawah yang melakukan usaha beternak itik pedaging yang berjumlah 30 peternak, dimana jumlah itiknya mencapai lebih dari atau sama dengan 600 ekor. Semua populasi dijadikan sebagai sampel. 


\section{Metode Pengumpulan Data}

Data yang dikumpulkan terdiri dari data primer dan data sekunder. Data primer diperoleh dari hasil interview langsung dengan responden melalui questioner yang telah dipersiapkan. Sedangkan data sekunder diperoleh dari instansi yang terkait maupun sumber lain yang berhubungan.

\section{Metode Analisis Data}

Data yang diperoleh dianalisis secara deskriptif dan dengan perhitungan ekonomi secara sederhana dengan rumus sebagai berikut:

$\mathbf{P d}=\mathbf{T R}-\mathbf{T C}$

$\mathrm{Pd}=$ Pendapatan Usahatani

$\mathrm{TR}=$ Total Penerimaan

TC $=$ Total Biaya. ${ }^{4}$

Dan untuk menghitung kontribusi pendapatan usaha ternak itik digunakan rumus di bawah ini :

Pendapatan Usaha Ternak Itik Pedaging

Total PendapatanPetani

X $100 \%$

Keterangan :

- Apabila kontribusi pendapatan usaha ternak > $30 \% \rightarrow$ kontribusinya tinggi.

- Apabila kontribusi pendapatan usaha ternak < $30 \% \rightarrow$ kontribusinya rendah. ${ }^{11}$

\section{HASIL DAN PEMBAHASAN Karakteristik Petani Sampel}

Sampel untuk penelitian ini berjumlah 30 orang dan karakteristik sampel dalam penelitian ini meliputi umur peternak, tingkat pendidikan, pengalaman beternak, jumlah tanggungan dan jumlah ternak yang dipelihara.

Tabel 1. Karakteristik Peternak Sampel di Desa Pematang Cengal Barat

\begin{tabular}{clc}
\hline No & Karakteristik & Rataan \\
\hline 1 & Jumlah Ternak (Ekor) & 706 \\
2 & Umur (Tahun) & 39,83 \\
3 & Pendidikan (Tahun) & 6 \\
4 & Pengalaman (Tahun) & 3 \\
5 & Jumlah Tanggungan (Jiwa) & 3 \\
\hline
\end{tabular}

Dalam rangka penyediaan bibit, peternak mendapatkannya dari membeli di toko. Bibit diantar oleh pihak toko sampai kerumah peternak. Bibit yang dipesan oleh peternak berjenis itik Mojosari dimana bila bibit yang dipesan ada yang mati maka pihak toko menggantinya. Bibit yang dipesan oleh peternak berumur satu hari dengan jenis itik jantan, alasan menggunakan bibit itik jantan karena harga bibitnya murah Rp 2.600/ekor dibandingkan dengan harga bibit itik betina yang lebih mahal Rp 5.000/ekor. Ketersediaannya cukup banyak, tahan terhadap penyakit dan pertumbuhan relatif cepat.

Dari hasil penelitian didapat bahwa peternak mudah untuk mendapatkan bibit, berapapun jumlah bibit itik yang dibutuhkan peternak tersedia di toko dengan akses yang cepat. Bibit itik yang dipesan satu minggu sudah sampai ke peternak dengan diantar tanpa ada biaya tambahan. Untuk memesan bibit, peternak mudah untuk memesannya dengan menelpon pihak toko dan bisa juga datang langsung ke tokonya.

\section{Tabel 2. Persepsi Peternak Terhadap Ketersediaan Bibit Usaha Ternak Itik Pedaging}

\begin{tabular}{|c|c|c|c|c|c|c|}
\hline No & Keterangan & $\begin{array}{c}\text { Jumlah } \\
\text { (Tersedia } \\
\text { Banyak) }\end{array}$ & $\begin{array}{c}\text { Mutu } \\
\text { (Bagus) }\end{array}$ & $\begin{array}{c}\text { Harga } \\
\text { (Murah) }\end{array}$ & $\begin{array}{c}\text { Akses } \\
\text { (Mudah) }\end{array}$ & $\begin{array}{c}\text { Jumlah Peternak } \\
(\%)\end{array}$ \\
\hline
\end{tabular}

\begin{tabular}{cccc}
\hline 1 & Bibit & Ya & Ya \\
\hline & Berdasarkan & hasil & penelitian \\
diketahui
\end{tabular}
bahwa semua responden menyatakan ketersediaan bibit itik pedaging tersedia. Dikatakan tersedia karena jumlah itik tersedia dalam jumlah yang banyak, dapat dipesan berapapun jumlah bibit, harga bibit murah karena terjangkau oleh peternak dan akses untuk memesan atau mendapatkan bibit mudah dikarenakan peternak tinggal memesan dan diantar sampai rumah serta kualitas bibit baik karena tidak ada bibit yang sakit atau cacat. ${ }^{10}$

\section{Ketersediaan Kandang}

Adapun persyaratan kandang yang harus dipenuhi adalah mudah dibersihkan, sirkulasi udara lancar dan cukup mendapatkan sinar matahari. Kandang dibuat atau dibangun dengan sederhana atau seadanya saja dengan bahan-bahan yang mudah didapat. Kandang disokong oleh tiang bambu, lantai kandang hanya tanah yang dilapisi oleh sekam padi tebal yang mudah didapat. Untuk dinding kandang menggunakan jaring-jaring yang dilapisi terpal dan atap sebagian yang harganya murah dan mudah didapat. Kandang untuk itik usia 1-15 hari dibangun berdekatan dengan rumah, karena itik masih rawan terhadap dingin, penyakit dan itik usia tersebut dipelihara dan diberi pakan di kandang sebelum siap untuk digembala. Itik usia 16 hari sampai panen, kandang itik dibangun di ladang persawahan untuk memudahkan dalam menggembala. Kandang itik yang telah diletakkan di ladang atau sawah jauh lebih sederhana bangunannya hanya atap dan dinding jaring saja.

Dari hasil penelitian didapat bahwa semua bahan yang diperlukan membangun kandang mudah didapat dan tersedia dengan harga 
murah. Bahan untuk membangun kandang tersedia dalam jumlah yang banyak seperti bambu, atap, jaring, terpal, plastik. Berapapun jumlah yang dibutuhkan peternak terhadap bahan tersebut tersedia dengan jumlah mencukupi dengan harga murah. Ketersediaan kandang dapat dilihat pada tabel berikut.

Tabel 3. Persepsi Peternak Terhadap Ketersediaan Input Kandang Usaha Ternak

\begin{tabular}{|c|c|c|c|c|c|c|}
\hline No & Keterangan & $\begin{array}{c}\text { Jumlah } \\
\text { (Tersedia } \\
\text { Banyak) }\end{array}$ & $\begin{array}{c}\text { Mutu } \\
\text { (Bagus) }\end{array}$ & $\begin{array}{c}\text { Harga } \\
\text { (Murah) }\end{array}$ & $\begin{array}{c}\text { Akses } \\
\text { (Mudah) }\end{array}$ & Jumlah Peternak (\% \\
\hline
\end{tabular}

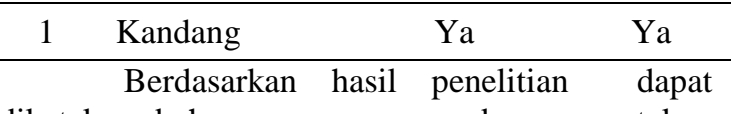

dikatakan bahwa semua responden menyatakan

ketersediaan kandang untuk usaha ternak tersedia.

Dikatakan tersedia karena semua bahan yang digunakan untuk membangun kandang tersedia dalam jumlah banyak, harga bahan yang digunakan untuk membangun kandang murah karena terjangkau. Mutu bahan bagus dikarenakan bahan tahan sampai beberapa kali pakai, serta akses untuk mendapatkan bahan tersebut mudah karena tersedia dekat lingkungan rumah.

\section{Ketersediaan Tenaga Kerja}

Curahan tenaga kerja merupakan faktor penting untuk berlangsungnya usaha. Dalam usaha ini keterlibatan tenaga kerja dimulai dari saat buat kandang hingga panen. Semua tenaga kerja yang

Ya ya 100

digunakan berasal dari dalam keluarga dalam hal
ini tenaga kerja laki-laki. Usaha ini merupakan usaha sampingan sehingga semuanya dikerjakan sendiri.

Diketahui bahwa jumlah penduduk di Desa Pematang Cengal Barat rata-rata berada pada usia 40 tahun yang artinya masih sangat produktif untuk mengelola usaha. Kemudian rata-rata penggunaan tenaga kerja cukup besar yakni sebesar 60,43 HKP. Hasil wawancara dan hasil penelitian menunjukkan bahwa ketersediaan tenaga kerja tersedia dalam jumlah banyak, artinya semua kebutuhan tenaga kerja terpenuhi. Dan akses untuk mendapatkan tenaga kerja mudah dikarenakan semua peternak menggunakan TKDK sehingga tidak tergantung pada orang lain. ${ }^{3}$

Tabel 4. Persepsi Peternak Terhadap Ketersediaan Tenaga Kerja Usaha Ternak

\begin{tabular}{ccccccc}
\hline No & Keterangan & $\begin{array}{c}\text { Jumlah } \\
\text { (Tersedia } \\
\text { Banyak) }\end{array}$ & $\begin{array}{c}\text { Mutu } \\
\text { (Berpengal } \\
\text { aman) }\end{array}$ & $\begin{array}{c}\text { Upah/HK(M } \\
\text { urah) }\end{array}$ & $\begin{array}{c}\text { Akses } \\
\text { (TKDK) }\end{array}$ & $\begin{array}{c}\text { Jumlah } \\
\text { Peternak } \\
(\%)\end{array}$ \\
\hline 1 & Buat Kandang & ya & Ya & Ya & Ya & 100 \\
2 & Pembesaran & ya & Ya & Ya & Ya & 100 \\
3 & Mengembala & ya & Ya & Ya & Ya & 100 \\
\hline
\end{tabular}

Dari hasil penelitian diperoleh bahwa pakan jenis pellet Rp5.000/kg dan untuk pakan semua responden menyatakan ketersediaan tenaga jenis dedak Rp1.000/kg. Pada usia ini itik diberi kerja baik, karena mudah didapat dan dilaksanakan pakan di dalam kandang secara teratur dengan oleh tenaga kerja dalam keluarga sehingga tidak tujuan agar itik tercukupi nutrisinya pada usia ada kendala. Kemudian akses untuk mendapatkan muda. Kedua pada usia 16 hari sampai panen, itik tenaga kerja mudah karena menggunakan tenaga diberi pakan alami dengan cara digembala di kerja dalam keluarga dan mutu tenaga kerja baik ladang atau di sawah.

karena telah berpengalaman rata-rata tiga tahun atau telah enam kali musim ternak melakukan usaha ternak itik pedaging ini.

\section{Ketersediaan Pakan Ternak}

Pada dasarnya pemberian pakan untuk itik pedaging memerlukan kandungan protein yang tinggi dan pemberian ada dua macam cara yaitu:

- Pakan yang berbentuk pellet yang sudah lengkap semua unsur nutrisinya, biasanya didapatkan dengan membeli.

- Pakan campuran dedak padi, jagung, bungkil kedelai, keong emas.

Peternak memberikan pakan pada itik dengan dua tahap, pertama itik usia 1-15 hari diberi pakan pellet dan dedak yang mudah didapat dengan harga yang murah. Diketahui bahwa harga

Dengan cara ini peternak mampu mengurangi biaya pemberian pakan dari pellet serta ketersediaan pakan alami yang cukup melimpah menjadikan tercukupi nurtrisinya. Semua jenis pakan itik mudah didapat dengan jumlah banyak, untuk pakan pellet dan dedak peternak dapat membelinya dengan harga murah. Kemudian untuk pakan alami tersedia banyak di sawah karena terus dalam kondisi berair yang menyediakan binatang-binatang kecil, keong emas, cacing dan lain-lain.

Akses untuk mendapatkan pakan pellet mudah dengan memesannya satu paket dengan bibit dan diantar sedangkan pakan dedak diperoleh dari kilang padi terdekat.

Tabel 5. Persepsi Peternak Terhadap Ketersediaan Pakan Usaha Ternak 


\begin{tabular}{llccccc}
\hline No & Keterangan & $\begin{array}{c}\text { Jumlah } \\
\text { (Tersedia } \\
\text { Banyak) }\end{array}$ & $\begin{array}{c}\text { Mutu } \\
\text { (Bagus) }\end{array}$ & $\begin{array}{c}\text { Harga } \\
\text { (Murah) }\end{array}$ & $\begin{array}{c}\text { Akses } \\
(\text { Mudah })\end{array}$ & $\begin{array}{c}\text { Jumlah } \\
\text { Peternak } \\
(\%)\end{array}$ \\
\hline 1 & Pellet & ya & Ya & Ya & Ya & 100 \\
2 & Dedak & ya & Ya & Ya & Ya & 100 \\
3 & Pakan Alami & ya & Ya & Ya & Ya & 100
\end{tabular}

Dari hasil penelitian diperoleh bahwa semua responden menyatakan ketersediaan pakan untuk usaha ini tersedia karena semua jenis pakan tersedia dalam jumlah banyak, pakan pellet dan pakan dedak selalu tersedia, kemudian mutu pakan baik, akses mendapatkan pakan mudah karena semua pakan tersedia di dekat lingkungan rumah serta harga pakan murah karena terjangkau.

\section{Sistim Pengelolaan Usaha}

Peternak masih mengusahakan ternak secara sederhana dengan bentuk pemeliharaan dengan tata pelaksanaannya tidak terprogram baik, salah satunya karena terlihat dari kandang yang hanya dibangun sekedarnya dimana kandang itik tidak permanen dan mudah dibongkar, lantainya dari tanah dan sekam padi saja, dinding kandang hanya dari jaring, plastik dan terpal, atap kandang sebagian besar dari terpal dan atap rumbia. Kandang hanya diutamakan untuk tempat berlindung dari teriknya matahari di waktu siang dan untuk melindungi ternak agar tidak lari atau pergi di waktu malam. Usaha ternak itik yang dilakukan secara sederhana tidak terlalu memikirkan hasil produksinya karena peternak menganggap tingkat usaha sampingan seperti ini masih menonjolkan kepentingan keluarga dimana aspek kepuasan lebih utama, karena peternak menganggap telah memiliki tabungan berbentuk ternak yang dapat dijual dan menambah pendapatan utama.

\section{Sistim Gembala}

Sistim gembala termasuk pemeliharaan semi intensif dimana ternak yang dipelihara sudah memperhatikan kandang ternak dan diberi makan tetapi sewaktu-waktu dilepas untuk mencari makan sewaktu ada peluang pada saat panen padi sawah atau tempat yang mempunyai potensi sumber pakan alami. Dapat juga sistim gembala itik ini digolongkan ke dalam sistim home based yaitu sistim pemeliharaan itik secara gembala yang hanya mengikuti panen di sekitar desa tempat tinggal peternakannya saja dan tidak memindahkan itik peliharaannya ke daerah lain. Ternak itik akan dibiarkan berkeliaran di saluran irigasi, kolam, genangan air di sekitar sawah dan sebagainya dengan memberi pakan tambahan di kandang.

\section{Sistim Pemberian Pakan}

Usaha ternak diberi pakan pellet dan dedak untuk usia 1-15 hari dengan tiga kali dalam sehari. Itik pedaging usia 1-15 hari diberi pakan di kandang dengan pellet dan dedak, usia 1-7 hari itik diberi pakan pellet murni tanpa dicampur karena itik kecil harus benar-benar terpenuhi nutrisinya. Usia 8-15 hari itik diberi pakan pellet dan dicampur dengan dedak, rata-rata satu hari peternak memberi pakan untuk semua ternaknya $15 \mathrm{~kg}$ untuk itik kecil dan $25 \mathrm{~kg}$ untuk itik yang mulai besar.

Itik usia 16 hari sampai panen diberi pakan alami dengan cara digembala di lahan pasca panen padi sawah, dimana kebutuhan pakan itik sangat tercukupi dengan adanya keong emas, telur keong emas, cacing, sisa-sisa padi, hama-hama kecil dan berbagai macam jenis hewan kecil. Dengan digembala di lahan pasca panen padi sawah, itik akan cepat besar karena itik membutuhkan air untuk berenang dan sawah meyediakan habitat yang cocok.

Pakan yang dibutuhkan untuk pembesaran itik pedaging jantan berbeda pada setiap fasenya. Pakan buatan pabrik belum ada yang khusus untuk itik pedaging, sehingga menggunakan pakan untuk ayam broiler dengan standar mutu pakan yaitu SNI 01-3908-2006. Pada fase starter, jenis pakannya menggunakan BR-I yaitu untuk itik 1-21 hari . Pertumbuhan maksimal pada fase starter, perlu ditunjang dengan pemberian pakan yang mengandung protein tinggi yaitu berkisar antara 20-25\%. Sedangkan pada fase finisher umur 21-90 hari menggunakan konsentrat ayam broiler finisher dengan cara dicampur bekatul dan pakan tambahan lainnya. Pemberian pakan setiap harinya didasarkan pada kondisi pertumbuhan itik-itik, pada fase starter diperkirakan 3 gram sampai 23 gram per ekor per hari dan fase finisher diperkirakan 24 gram sampai dengan 73 gram per ekor per hari. ${ }^{9}$

\section{Sistim Pemberian Minum dan Vitamin}

Pemberian minum dan vitamin diberikan pada itik yang dipelihara di kandang saja yaitu pada usia 1-15 hari dan untuk usia 16 hari sampai panen itik pedaging tidak diberi minum dan vitamin lagi. Minum diberikan dengan menggunakan tempat minum dan terus diganti tiga kali sehari. Pemberian vitamin dilarutkan pada minum dengan takaran untuk 1 sendok takar dilarutkan dengan 1 liter air.

Air minum untuk anak itik harus selalu tersedia dalam kondisi bersih dan diberikan di dekat tempat pakan. Tempat minum sebaiknya dibuat sedemikian rupa sehingga aman dan anak itik tidak dapat masuk ke dalam tempat minum. Bagian bawah tempat minum dapat diberi tempat 
penampung air yang tercecer. Itik yang bermainmain di dalam tempat minum harus segera dikeluarkan dan apabila bulunya terlalu basah perlu dikeringkan. Untuk menunjang pertumbuhan itik, pada periode anakan perlu diberikan vitamin baik yang berasal dari buatan pabrik maupun dibuat sendiri. Pada itik periode dewasa air minum harus selalu tersedia dan diganti setiap hari atau apabila sudah kotor. ${ }^{8}$

\section{Sistim Pencegahan Penyakit}

Pencegahan penyakit adalah lebih baik dari pada mengobatinya dan setiap penyakit belum tentu menyebabkan kematian, tetapi bisa menurunkan produksi. Adapun pencegahan penyakit yang dilakukan adalah :

- Menjaga kebersihan dan menghindari makanan basi, busuk dan tercemar pestisida.

- Menghidari itik memakan bangkai.

- Memisahkan itik yang sehat dari yang sakit.

- Menjaga kebersihan kandang, menjaga lantai terus kering dengan mengganti sekam padi atau jerami ketika telah basah.

- Pemberian vitamin pada itik agar tetap sehat dan kuat terhadap penyakit.

Penyakit yang menyerang itik adalah penyakit lumpuh tetapi relatif kecil dimana itik yang terkena lumpuh harus dipisahkan dan disuapi makan minumnya. Kebanyakan itik mati di waktu kecil ketika di kandang karena tertimpa, kedinginan, kalah makan dan untuk mengatasinya diberi sekat-sekat pada kandang.

Pencegahan penyakit adalah salah satu kewajiban yang tidak bisa dihindari apabila usaha ini diharapkan memberi keuntungan. Berbagai cara pengendalian antara lain :

- Memproteksi lokasi kandang agar tidak mudah dimasuki oleh binatang lain.

- Melakukan disinfektan kandang dan peralatan.

Tabel 6. Rataan Biaya Produksi Usaha Ternak Itik Pedaging (permusim/peternak)

\begin{tabular}{clrr}
\hline No & Uraian & Rataan $(\mathbf{R p )}$ & Persentase $(\%)$ \\
\hline 1 & Biaya Bibit & 1.837 .333 & 30,17 \\
2 & Biaya Pakan & 1.178 .000 & 19,34 \\
3 & Biaya Vitamin & 86.633 & 1,43 \\
4 & Tenaga Kerja & 2.719 .500 & 44,65 \\
5 & Perlengkapan & 35.305 & 0,59 \\
6 & Kandang & 181.174 & 2,97 \\
7 & Biaya Listrik & 51.667 & 0,85 \\
\hline & Jumlah & $\mathbf{6 . 0 8 9 . 6 1 2}$ & $\mathbf{1 0 0}$ \\
\hline
\end{tabular}

\section{Penerimaan Usaha Ternak Itik Pedaging}

Rataan penerimaan usaha ternak itik pedaging sebesar Rp 13.911 .333 per musim/ peternak dengan harga jual itik pedaging $\mathrm{Rp}$ 20.000 per ekor. Pendapatan usaha ternak itik
- Melakukan pembersihan kandang yang habis dikosongkan.

- Menjaga kebersihan dan sanitasi saluran kandang peternakan.

- Melakukan tindakan vaksinasi. ${ }^{10}$

\section{Sistim Pemanenan}

Usaha ternak itik pedaging dipanen ketika usia telah mencapai 2 bulan lebih 1 minggu atau sekitar 67 hari dimana pada usia ini beratnya telah mencapai rata-rata $1,3 \mathrm{~kg}-1,5 \mathrm{~kg}$ per ekor. Peternak menjualnya kepada para agen yang telah memesan sebelum panen dengan harga Rp 20,000 per ekor.

Proses pembesaran itik pedaging jantan dibagi menjadi dua fase. Pertama fase starter yaitu pembesaran itik pedaging jantan dari umur 1-21 hari dan kedua yaitu fase finisher proses pembesaran itik pedaging jantan dari umur 22-90 hari. Laju pertumbuhan optimal itik pedaging jantan merupakan salah satu jaminan dalam mendapatkan itik pedaging jantan yang baik. Untuk mendapatkan hasil yang bermutu baik pada saat pemanenan maka perlu dilakukan pemilihan terhadap itik pedaging jantan sesuai dengan kondisi beratnya, sebelum itik dimasukkan ke dalam transportasi khusus sebaiknya itik dimasukkan ke keranjang dan berangkat pada malam hari agar tidak kepanasan, serta dianjurkan penjualan itik ke tempat-tempat pemotongan unggas dan tidak langsung dijual ke pasar. ${ }^{12}$

\section{Analisis Ekonomi Usaha}

Biaya produksi dalam usaha ternak itik pedaging meliputi biaya bibit, biaya pakan, biaya vitamin, tenaga kerja, biaya perlengkapan kandang, biaya bangunan kandang dan biaya listrik. Untuk tenaga kerja menggunakan tenaga kerja dalam keluarga. pedaging diperoleh dari selisih antara total penerimaan usaha ternak itik pedaging dengan biaya produksi yang dikeluarkan peternak selama proses pemeliharaan.

Tabel 7. Rataan Pendapatan Usaha Ternak Itik Pedaging (Permusim/Peternak)

\begin{tabular}{clc}
\hline No & Uraian & Jumlah (Rp) \\
\hline 1 & Penerimaan Usaha Ternak Itik Pedaging & 13.911 .333 \\
2 & Biaya Produksi Usaha Ternak Itik Pedaging & 6.089 .612 \\
3 & Pendapatan Usaha Ternak Itik Pedaging & 7.821 .721 \\
\hline
\end{tabular}


utama. Semua kegiatan pekerjaan petani dilaksanakan dalam waktu berbeda akan tetapi dalam satu periode musim yang sama yaitu enam bulan. Komposisi curahan waktu pekerja petani dilaksanakan pada minggu kesatu dalam bulan kesatu sampai dengan pada minggu ketiga dalam bulan kesatu (23 hari pembibitan). Kemudian penanaman padi dilaksanakan pada pertengahan minggu keempat atau 24 hari setelah pembibitan yang dilaksanakan dalam bulan kesatu.

Pemanenan padi dilaksanakan pada minggu keempat dalam bulan keempat sehingga dalam hitungan hari dapat dihitung sekitar 90 hari atau sekitar tiga bulan, kemudian untuk menjaga burung petani mulai melaksanakannya pada minggu keempat dalam bulan ketiga. Pemeliharaan bibit itik di kandang mulai dilaksanakan pada minggu ketiga dalam bulan keempat yaitu satu minggu sebelum padi sawah dipanen sampai dengan itik berusia 15 hari, kemudian itik mulai digembala pada minggu kestau dalam bulan kelima sampai dengan itik dapat dipanen yaitu pada minggu ketiga dalam bulan keempat.

\section{Kontribusi Pendapatan Usaha Ternak} Terhadap Pendapatan Petani

Total pendapatan petani (keluarga peternak) adalah penjumlahan pendapatan usaha ternak itik pedaging dan pendapatan luar usaha ternak itik pedaging yaitu usahatani padi sawah. Di daerah penelitian sumber pendapatan petani (keluarga peternak) adalah berasal dari usahatani padi sawah dan usaha ternak itik pedaging yang sifat usahanya rutin dilaksanakan setiap musim. Usahatani padi sawah merupakan usahatani utama di daerah penelitian sedangkan usaha ternak itik pedaging merupakan sebagai usaha sampingan atau bisa dianggap sebagai tabungan. Usahatani padi sawah dan usaha ternak itik pedaging berjalan bergantian dalam satu musim, artinya setelah usahatani padi sawah panen barulah usaha ternak itik pedaging berjalan dengan memanfaatkan waktu menganggur petani.

Walaupun sebagai usaha sampingan, namun usaha ternak ini juga merupakan salah satu sumber pendapatan yang dapat diperoleh satu tahun dua kali, sehingga memberi sumbangan yang cukup besar terhadap pendapatan petani (keluarga peternak). Usahatani padi sawah juga dapat dipanen dua kali dalam setahun, namun harus menunggu 3 bulan (100 hari) hasilnya dapat dipanen dan dapat langsung digunakan untuk konsumsi keluarga dan dijual. Sedangkan usaha ternak itik pedaging hanya butuh waktu 2 bulan (67 hari) untuk dipanen.

Pendapatan petani total diperoleh dengan menambahkan pendapatan usahatani padi sawah dengan usaha ternak itik pedaging seperti di bawah ini:

Tabel 8. Rataan Kontribusi Pendapatan Usaha Ternak Terhadap Pendapatan Total

\begin{tabular}{clcc}
\hline No & Uraian & $\begin{array}{c}\text { Jumlah } \\
(\mathbf{R p / m u s i m})\end{array}$ & $\begin{array}{c}\text { Kontribusi } \\
(\boldsymbol{\%})\end{array}$ \\
\hline 1 & Pendapatan Usahatani Padi Sawah & 5.429 .233 & 40,97 \\
2 & Pendapatan Usaha Ternak Itik Pedaging & 7.821 .721 & 59,03 \\
3 & Total Pendapatan Petani (keluarga Peternak) & 13.250 .954 & 100 \\
\hline
\end{tabular}

Kontribusi pendapatan usaha ternak itik terhadap pendapatan total adalah $59,03 \%$ artinya lebih besar dibandingkan dengan pendapatan usahatani padi sawah $40,97 \%$. Hal ini menunjukkan bahwa usaha ternak itik pedaging di Desa Pematang Cengal Barat memberikan kontribusi pendapatan yang tinggi terhadap total pendapatan petani per musim.

\section{KESIMPULAN DAN SARAN}

\section{Kesimpulan}

1. Ketersediaan input atau faktor produksi (bibit, kandang, tenaga kerja, pakan) cukup tersedia, akses mudah dan harga terjangkau.

2. Sistim pengelolaan usaha ternak itik pedaging adalah semi intensif dimana ternak yang dipelihara sudah memperhatikan kandang ternak dan diberi makan tetapi sewaktu-waktu dilepas.

3. Rataan pendapatan usaha ternak itik pedaging adalah sebesar Rp7.821.721 per peternak/musim selama 2 bulan.

4. Kontribusi pendapatan dari usaha ternak itik pedaging terhadap pendapatan petani adalah lebih besar dibandingkan pendapatan bersumber dari mata pencaharian pokok usaha tani padi sawah.

\section{Saran}

1. Diharapkan kepada pemerintah agar memberikan perhatian kepada peternak melalui kegiatan penyuluhan dan bantuan bibit, pakan dan teknologi kandang.

2. Diharapkan kepada peternak untuk menjadikan usaha ternak ini sebagai usaha pokok yang pemeliharaannya dapat dilakukan secara semi ekstensif atau intensif dengan memanfaatkan potensi lahan sawah secara maksimal melalui pemeliharaan itik dengan jumlah besar dan membentuk kelompok ternak.

\section{REFERENSI}

1. Sumarno dan Anang. 2010. Kemelaratan Petani Kecil. BPTP. Bogor.

2. Ali dan Febrianti. 2009. Peformans Itik Pedaging.Jurnal Peternakan Vol 6 No 1 Februari 2009. Pekanbaru.

3. Hasnawati. 2013. Analisis Pendapatan Usaha Ternak Itik Pedaging. Sosial Ekonomi Pertanian. Univ. Hasanuddin Makasar. 
4. Soekartawi. 1995. Analisis Usahatani.UIPress. Jakarta

5. Zulfauzi. 2011. Analisis Ekonomi Usaha Ternak Itik dan Sumbangannya Terhadap Pendapatan Keluarga. USU. Medan.

6. Kartasapoetro, A. G. 1988. Pengantar Ekonomi Produksi Pertanian. Bina Aksara. Jakarta.

7. Safarudin, M. 2000. Pengaruh Pemberian Pakan Pada Sistim Pemeliharaan Intensif dan Ekstensif Terhadap Produksi dan Kualitas Telur Itik. IPB Bogor.

8. Sukmaya. 2010. Budidaya Ternak Itik. BPTP. Jawa Barat.

9. PPUK, 2010. Komoditas Budidaya Itik Pedaging.Bank Indonesia. Jakarta.

10. Saleh, E. 2004. Pengelolaan Ternak Itik di Perkarangan Rumah. Jurusan Peternakan Fakultas Pertanian USU. Medan.

11. Soekartawi. 1994. Teori Ekonomi Produksi. Raja Grafindo Persada. Jakarta.

12. Rasyaf, M. 2002. Beternak Itik. Edisi ke-16. Kanisius. Yogyakarta. 